\title{
Green Synthesis of Copper Oxide Nanoparticles from Catharanthus Roseus Plant Leaf Extract and Its Investigation
}

\author{
K. Sofiya Dayana ${ }^{1,2, *}$, R. Jothimani ${ }^{2,3}$, S.C. Vella Durai ${ }^{4, \dagger}$ \\ ${ }^{1}$ Department of Physics, Sarah Tucker College (Autonomous), Tirunelveli 627007, Tamilnadu, India \\ ${ }^{2}$ Department of Physics, Sadakathullah Appa College (Autonomous), Tirunelveli 627011, Tamilnadu, India \\ ${ }^{3}$ Department of Physics, Fatima College for Women, Madurai 625001, Tamilnadu, India \\ ${ }^{4}$ Department of Physics, JP College of Arts and Science, Tenkasi 627852, Tamilnadu, India \\ (Affiliated to Manonmaniam Sundaranar University, Thirunelveli)
}

(Received 10 January 2021; revised manuscript received 15 February 2021; published online 25 February 2021)

\begin{abstract}
In recent years, nanotechnology is a burning field for researchers. Studies on the green synthesis of metal oxide nanoparticles (NPs) have been carried out with various plant extracts. Considering the huge possibility of plants as sources, this work expects to apply green preparation for the copper oxide $(\mathrm{CuO})$ NPs as an option in contrast to regular techniques. Plant separates ready to lessen the metal particles in a more limited time, while microorganism-based techniques require a more extended time. The simple accessibility of plants in nature makes them more favored organic assets than microorganisms. CuO NPs were infused by green synthesis procedure from copper sulphate solution through the aqueous extract of catharanthus roseus, a relentless ratio of plant extract to metal ion was prepared, then the color change was observed which proved the formation of NPs. This method is fast, straightforward with no unsafe synthetic substances as lessening or balancing out specialists, and prudent to blended CuO NPs. The NPs obtained were analyzed by X-ray diffraction (XRD), UV-DRS spectroscopy method, Fourier-transform infrared spectroscopy (FTIR), scanning electron microscopy (SEM), and zeta potential. The prepared NPs were found in crystalline size range of $43.7 \mathrm{~nm}$. The SEM images confirmed and explained that the NPs shape is a spherical shape with an average diameter of $43 \mathrm{~nm}$. FTIR analysis confirmed that $\mathrm{Cu}-\mathrm{O}$ peaks are obtained. The $\mathrm{CuO}$ demonstrates direct bandgap energy of $2.04 \mathrm{eV}$ from UV-DRS spectroscopy. Zeta potentials analyzed explained the narrow size of NPs stability. CuO NPs, due to their unique physical and chemical properties and low-cost preparation, have been of great interest recently. $\mathrm{CuO}$ NPs have been applied as dietary added substances, grease supplements, compound sensors, covering materials notwithstanding countless biotechnological and drugs applications. The article explains the comfortable application of catharanthus roseus extract as an efficient preparation of $\mathrm{CuO} \mathrm{NPs} \mathrm{through} \mathrm{green} \mathrm{synthesis} \mathrm{technique} \mathrm{to}$ obtain crystalline material.
\end{abstract}

Keywords: Catharanthus roseus, CuO, Green synthesis, Nanoparticles, Zeta potential.

\section{INTRODUCTION}

In the latest method, nanotechnology could be an aglow area for the researchers. Green synthesis techniques have different ways in the field of nanoscience. The nanotechnology, which gets rid of manufacture cost and more energy, is being developed within the usual technique of preparing nanoparticles (NPs) [1,2]. Green synthesis also includes cancellation of complex set of ways, the choice of solvent water, change of toxic reluctant and stabilizing agent with renewable and sustainable materials. The biological synthesis of nanomaterials also uses algae, fungi, yeasts, and bacteria. The implementation of plant extracts for metal hybrid NPs preparation is currently a replacement research focus that has obtained [3]. Material is in the nanoscale range, which has novel characteristics they possess, application of such material is within the chip technology. Materials are reduced to the size also confined by the flexibility to tune the property of nanomaterials for applications in optoelectronics, biomedicine, and so on. The biomolecule in plants has essential oils (terpenes, eugenol), carbohydrates are found in its active functional groups like aldehyde, amine and carboxyl entities. Catharanthus roseus could be habitually used as a medicinal plant. It widely grows up to one meter height in subtropical area, and it is an herb. It retains wellknown antifungal, antioxidant, antibiotic, wound healing and antibacterial activities. Herewith, for the first time, we prepared an extract of copper oxide $(\mathrm{CuO}) \mathrm{NPs}$ from catharanthus roseus using the reduction of oxide ions present within the solution of copper sulphate with water [4]. $\mathrm{CuO} N \mathrm{NPs}_{\text {sain }}$ considerable attention because of their excellent optical, electrical, physical, and magnetic properties. The prospect of manipulating the band gap of $\mathrm{CuO}$ NPs through quantum (bulk) confinement from 1.2 to more than $2 \mathrm{eV}$ acts as a noteworthy optical property. With altered band gap, $\mathrm{CuO}$ NPs become a highly attractive and versatile material for more applications [5]. The structural and optical properties of green-synthesized $\mathrm{CuO}$ NPs prepared using Catharanthus roseus leaf extract were characterized by XRD, UV-DRS, FTIR, SEM, and zeta potential.

\footnotetext{
*k.sofiyadayana@gmail.com

†duraipree@gmail.com
} 


\section{EXPERIMENTAL}

\subsection{Materials}

Copper sulphate is employed for the synthesis of $\mathrm{CuO}$ NPs which was purchased from madras scientific suppliers, India, the leaves of catharanthus roseus collected from the garden were utilized during this work.

\subsection{Synthesis of Copper Oxide Nanoparticles}

$\mathrm{CuO}$ NPs were unified by co-precipitation method. The leaves of catharanthus roseus were collected and washed thoroughly with water to create them free from dust particles and surface contamination. They were grinded with the help of a mixer grinder, and then the extract was taken from the grinded paste. It had been then refined and employed for the synthesis process. Copper sulfate $\left(\mathrm{CuSO}_{4} 5 \mathrm{H}_{2} \mathrm{O}\right)$ solution of $0.2 \mathrm{M}$ was prepared using double distilled water. The prepared leaf extract of catharanthus roseus was added dropwise into the $\mathrm{CuSO}_{4} 5 \mathrm{H}_{2} \mathrm{O}$ solution separately until the precipitate forms. The color change declares the reduction of copper ions and so this confirms the formation of oxide NPs $[6,7]$ shown in Fig. 1 . The precipitate is collected in a Petri dish and dried within the hot-air oven for some time at $100{ }^{\circ} \mathrm{C}$ followed by the calcination process with the resulting yield of about $3.7 \mathrm{~g}$. Dried precipitates were made into a fine powder with the help of a mortar and used for further characterization to study the structural and optical properties of the synthesized NPs.

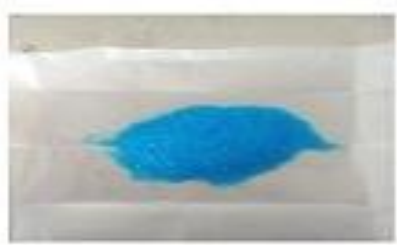

CuSO4.5H2O

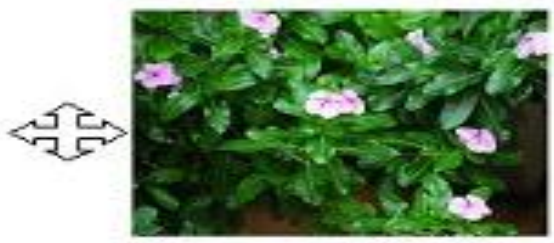

Catharanthus roseus

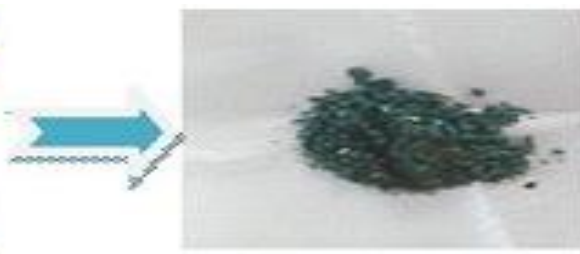

CuO NPs

Fig. 1 - Reaction process of $\mathrm{CuO}$ NPs using leaf extract of Catharanthus roseus

\subsection{Materials Characterization of Green Synthesized CuO NPs}

The green synthesized NPs were analyzed by XRD (XPERT-PRO Diffractometer 34 using CuKa1 radiation, $\lambda=1.540 \mathrm{~nm}$ ). The scattered angle of the above said analysis is $10^{\circ}$ to $80^{\circ}$ ( $2 \theta$ values). The functional group of NPs was found using FTIR (JASCO FTIR4100). The wavelength of the above said analysis is $400-4000 \mathrm{~cm}^{-1}$. The sample was recorded by using UVDRS spectroscopy (PANanlytival/X Pert3 Powder). The particle shape was analyzed by using SEM (JEOL Model JFC1600). Zeta potential and stability were analyzed by using a Malvern Zetasizer Nanosizer.

\section{RESULTS AND DISCUSSION}

\subsection{XRD Analysis}

The XRD diagram showing the origination of $\mathrm{CuO}$ NPs with catharanthus roseus leaf extract as a reductant is plotted in Fig. 2. The XRD patterns have recorded in terms of the diffracted X-ray intensity versus $2 \theta$. To investigate the crystalline size and phase purity of the prepared $\mathrm{CuO}$ NPs, XRD studies were explained. The peaks at $2 \theta$ values of $16.51^{\circ}, 18.70^{\circ}, 22.31^{\circ}, 23.94^{\circ}$, $25.69^{\circ}, 26.91^{\circ}, 31.62^{\circ}, 32.55^{\circ}, 37.03^{\circ}$, and $43.44^{\circ}$ correspond to the lattice planes of the orthorhombic crystal structure of CuO NPs (020), (103), (212), (220), (123), (222), (133), (321), (026), and (404), respectively; these results are in good agreement with the JCPDS file No. 7718-98. The purposed crystallite sizes $(d)$ of the $\mathrm{CuO}$ NPs were calculated using Scherrer formula $[8,9]$

$$
d=k \lambda / \beta \cos \theta,
$$

where $d$ is the average crystallite size (nm), $k$ is the grain shape factor (0.9), $\lambda$ is the $\mathrm{X}$-ray wavelength (nm), $\beta$ is the line broadening at half the utmost intensity in radians, and $\theta$ is the Bragg diffraction angle of the $2 \theta$ peak. The size of $\mathrm{CuO}$ crystallites is around $43 \mathrm{~nm}$. The additional peaks present in the XRD pattern could even ensue the presence of some impurities within the sample which might be removed by further calcination.

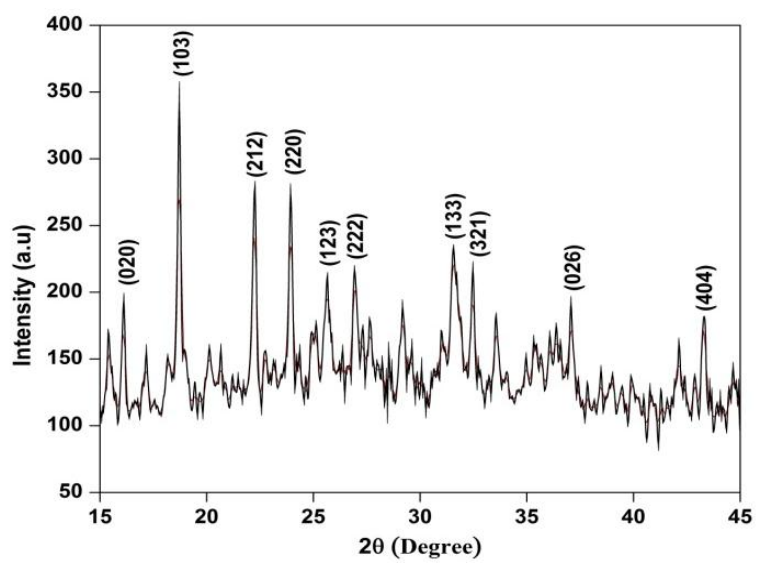

Fig. 2 - XRD pattern of $\mathrm{CuO} \mathrm{NPs}$

The particle size calculated confirms that the sizes of $\mathrm{CuO}$ NPs are in nanoscale. Some XRD peaks were obtained, other than $\mathrm{CuO}$ NPs diffraction peaks in the spectrum and this indicates the less phase purity. This result is very close (crystallite size) and in good agreement with the article of Sorbiun et al. [10], but only the leaf extract is different. This XRD result is found in very close agreement with other previous research articles, but it has a very less difference in size only and a good crystalline size compared to most published research articles [10]. 


\subsection{FTIR Analysis}

FTIR spectra were analyzed to characterize and identify the biomolecules of leaf extract of catharanthus roseus. The FTIR spectral analysis of $\mathrm{CuO} \mathrm{NPs} \mathrm{in} \mathrm{con-}$ comitance with the catharanthus roseus leaf extract is depicted in Fig. 4. FTIR analysis was carried out to confirm the probable biomolecule and its response to the formation of functional groups of $\mathrm{CuO}$ NPs. Some peaks of FTIR are lattice vibration modes that shows functional group of molecules adsorbed on $\mathrm{CuO}$ NPs. The shift of the peaks closest to the height $1618 \mathrm{~cm}^{-1}$ was attributed to the binding of $\mathrm{C}=\mathrm{O}$ group with the NPs [11]. The peaks are $1107 \mathrm{~cm}^{-1}$, which indicates amides. The FTIR spectra divulged the vibrations within the $400-600 \mathrm{~cm}^{-1}$ region attributable to $\mathrm{Cu}-\mathrm{O}$ vibrations, confirming the formation of $\mathrm{CuO}$ NPs. One absorption peak is $608 \mathrm{~cm}^{-1}$ and confirms the vibration of the $\mathrm{Cu}-\mathrm{O}$ functional groups. The stretching vibrations of the hydroxyl functional group are exhibited at $3376 \mathrm{~cm}^{-1}$ dense and broad peak $[12,13]$. Thus, the FTIR analysis of $\mathrm{CuO} \mathrm{NPs}$ by green synthesis is in good agreement with the XRD result.

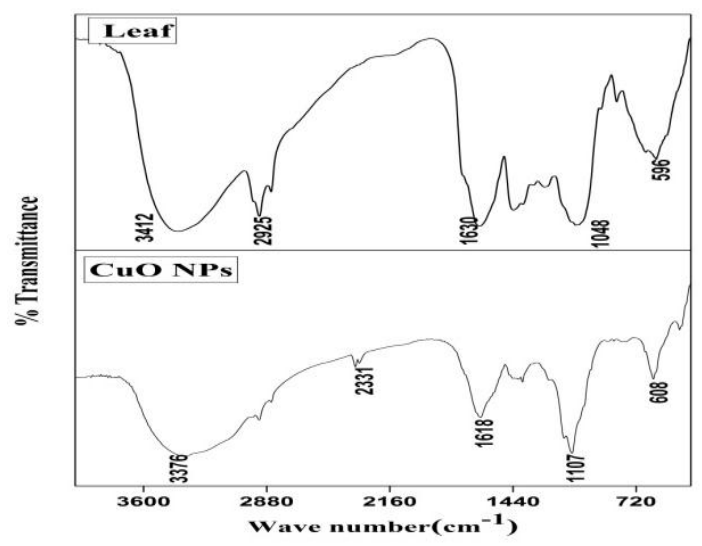

Fig. 3 - FTIR spectra of leaf and CuO NPs

\subsection{UV-DRS Analysis}

The UV-DRS analysis was performed and the band gap energy of $\mathrm{CuO}$ NPs was found as shown in Fig. 4. The sample encompasses powerful and clear measured radiation peaks at $607 \mathrm{~nm}$. The energy band gap $\left(E_{g}\right)$ of $\mathrm{CuO} \mathrm{NPs}$ was found from the energy values corresponding to the premise that the junction of horizontal and vertical sections of the spectra is $2.04 \mathrm{eV}$. It is explained that the prepared $\mathrm{CuO} N \mathrm{NP}$ can be used as a photocatalyst. The measured difference between the band gap (calculated) and the reported value in some research articles arises from density and size of $\mathrm{CuO}$ NPs. The reflectance spectrum is additionally studied using the Kubelka-Munk relations. To convert the reflectance information into Kubelka-Munk operates [14] (equivalent to the absorption coefficient) $F(R)$, the following relation was used:

$$
F(R)=(1-R)^{2} / 2 R,
$$

where $R$ is that the reflectance value. The band gap energy of NPs was computed from the improvement of the Kubelka-Munk operate with photon energy. Fig. 4 shows the Kubelka-Munk plots for the $\mathrm{CuO}$ NPs which are used to verify their band gap energy related to their direct transitions. The $\mathrm{CuO}$ demonstrates a direct band gap energy of $2.04 \mathrm{eV}$ that has the characteristics of wide-band gap semiconductor materials with the flexibility to work at higher temperatures.

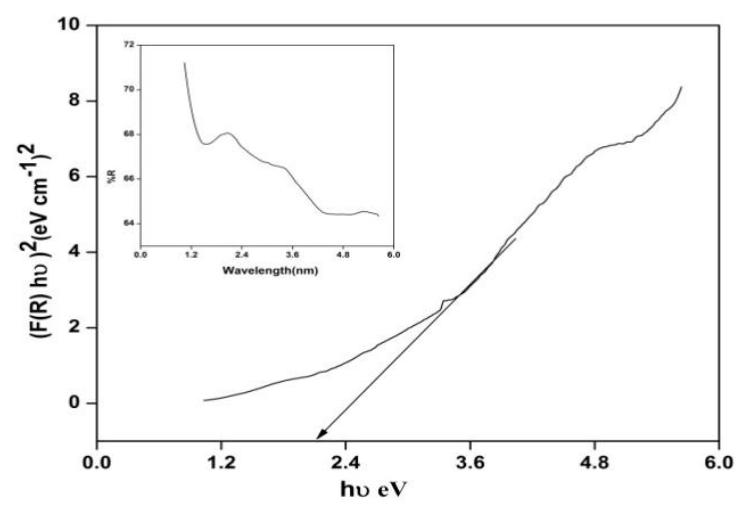

Fig. 4 - Tauc's plot of $\mathrm{CuO} \mathrm{NPs}$

\subsection{SEM Analysis}

Surface morphology and elemental organization of the $\mathrm{CuO}$ NPs were scrutinized by the immoderate simulate scanning microscope. The structure of $\mathrm{CuO}$ NPs with various morphology is shown in Fig. 5. It is clearly seen that green prepared $\mathrm{CuO}$ NPs are mainly comprised of spherical agglomeration. The prepared NPs have nanoscale sizes and their structure is inhomogeneous. Fig. 5 indicates that, only a few NPs with spherical shape were prepared. Some NPs were separated from each other. The diameter of fully developed and welldefined agglomerated $\mathrm{CuO} \mathrm{NPs}$ is around $43 \mathrm{~nm}$. Thus, SEM images have confirmed the nano nature of the prepared CuO NPs. This result is in good agreement with previous articles [15], in contrast to the particle size.

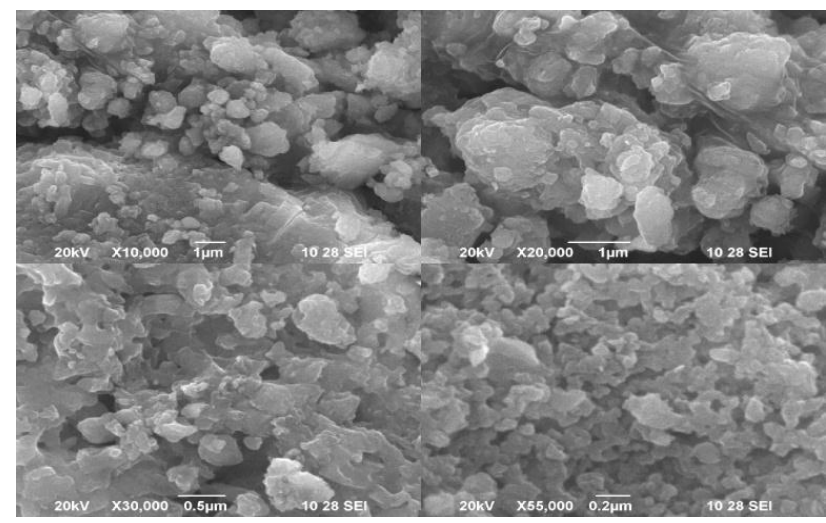

Fig. 5 - SEM images of CuO NPs

\subsection{EDX Analysis}

The analysis through EDX spectrometers validates the fundamental presence of $\mathrm{CuO}$ NPs and also explains the composition and chemical formation. The EDX spectra are shown in Fig. 6. EDX peak for $S$ usually indicates the presence of plant extracts used for synthesis [17]. Therefore, the EDX spectra for CuO NPs corroborate the presence of oxygen and copper within 
the NPs without impurity [16]. The EDX spectrum confirms the presence of $\mathrm{CuO}$ NPs in the sample. From Fig. 6, it is clear that the EDX spectrum confirms the formation of $\mathrm{CuO} \mathrm{NPs}$ from catharanthus roseus leaf extract. It is shown that the EDX pattern of CuO NPs prepared from catharanthus roseus confirms the characteristic peaks of copper and oxygen only. The narrow and strong diffraction peaks of NPs found that the prepared particles are purely crystalline in nature. Hence, it can be concluded that the green synthesis method is a good method for controlling the crystallite size. These results are in good agreement with previous articles [18] but have slight differences with variation in crystallite size. These results confirm the XRD results.

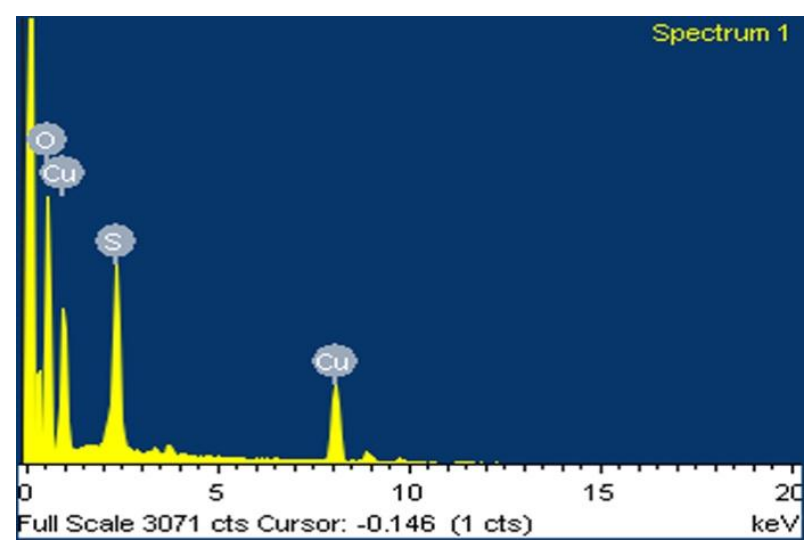

Fig. 6 - EDX spectrum of $\mathrm{CuO}$ NPs

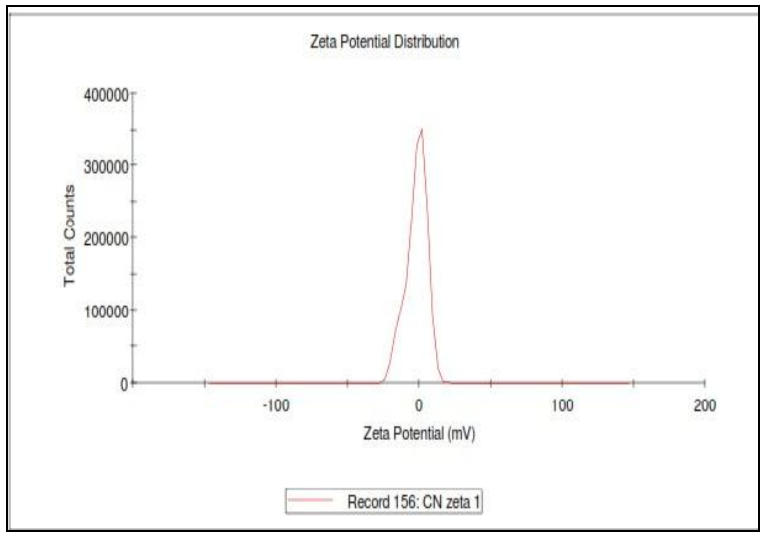

Fig. 7 - Zeta potential of $\mathrm{CuO}$ NPs

\section{REFERENCES}

1. Zh.T. Nakysbekov, M.Zh. Buranbayev, M.B. Aitzhanov, G.S. Suyundykova, M.T. Gabdullin, J. Nano- Electron. Phys. 10, 03010 (2018)

2. M. Jayanthi, N. Sowbala, G. Rajalakshmi, Kanagavalli, V. Sivakumar, Int. J. Pharm. Pharm. Sci. 2, 114 (2010).

3. S.M. Yedurkar, C.B. Maurya, P.A. Mahanwar, J. Mater. Environ. Sci. 8(4), 1173 (2017).

4. S. Honary, H. Barabadi, E.G. Fathabad, F. Naghibi, Digest J. Nanomater. Biostruct. 7(3), 999 (2012).

5. K. Subashini, S. Prakash, V. Sujatha, Asian J. Chem. 31, 1899 (2019).

6. D.G. Sant, T.R. Gujarathi, S.R. Harne, S. Ghosh, R. Kitture, S. Kale, B.K. Chopade, K.R. Pardesi, L.A. Philippense, J. Nanopart. 182320, 1 (2013).

7. J. Sarkar, D. Chattopadhyay, S. Patra, S.S. Deo, S. Sinha,

\subsection{Zeta Potential Analysis}

Zeta potential is taken into consideration as a charge found on the NPs surface, the upper magnitude of which improves the dispersion stability of NPs. The zeta potential gives the sign of the charge available on the particle surface. The zeta potential of oxide NPs prepared using extract of catharanthus roseus leaf well dispersed in water was found to be $-1.88 \mathrm{mV}$ [19], with relative ease suggesting its application for preparation of nanofluids. The slightly negative charges on the NPs probably resulted in the high stability of the oxide NPs. The high negative zeta potential indicates a very strong repulsion force between the particles indicating quality and stability.

\section{CONCLUSIONS}

Green synthesis of $\mathrm{CuO} \mathrm{NPs}$ by implementing catharanthus roseus leaf extract is one of the new approaches within the sector of nanotechnology. The copper oxide NPs were prepared by using the leaf extract of catharanthus roseus plant as a reductant. The obtained $\mathrm{CuO}$ NPs were orthorhombic in structure with crystalline sizes of $43.7 \mathrm{~nm}$. The CuO NPs have a band gap of $2.04 \mathrm{eV}$, which ends up as a promising material of wide-band gap semiconductors. Zeta potential reveals high negative steadiness with a value of $-1.88 \mathrm{mV}$. The morphology and structure analysis is confirmed by XRD, SEM and EDX reveal the character of prepared $\mathrm{CuO}$ NPs. Thus, $\mathrm{CuO}$ NPs could find interesting applications within the sector of semiconductor materials. This green synthesis method can be useful for producing $\mathrm{CuO}$ NPs in a simple, low cost and environmentally friendly way. It is expected that these $\mathrm{CuO}$ NPs are used as a photocatalyst.

\section{ACKNOWLEDGEMENTS}

K. Sofiya Dayana (registration No. 18221192132002) is thankful to authorities of Department of Physics, Sarah Tucker College (Autonomous), Tirunelveli, Department of Physics, Sadakathullah Appa College (Autonomous), Tirunelveli, India. The authors would also like to thank Manonmaniam Sundaranar University, Abishegapatti, Tirunelveli, Tamilnadu, India for providing necessary research facilities.

M. Ghosh, A. Mukherjee, K. Acharya, Digest J. Nanomat. Biostruct. 6, 563 (2011)

8. S.C. Vella Durai, E. Kumar, J. Ovonic Res. 16, 173 (2020)

9. S. Li, J. Zhang, Z. Hu, S. Guo, Z. Wu, P. Yan, F. Pan, RSC Adv. 5, 72857 (2015).

10. M. Sorbiun, E.S. Mehr, A. Ramazani, S.T. Fardood, Int. J. Environmen. Res. 12, 29 (2018).

11. R.R. Kannan, W.A. Stirk, J.V. Staden, S. Afr. J. Bot, 86, 1 (2013).

12. M.R. Hosseini, M. Schaffie, M. Pazouki, E. Darezereshki, M. Ranjbar, Mater. Sci. Semicond. Proc. 15, 222 (2012).

13. S.C. Vella Durai, R. Ganapathi Raman, E. Kumar, D. Muthuraj, J. Nano- Electron. Phys. 11, 05011 (2019).

14. N. Anandhavalli, B. Mol, S. Manikandan, N. Anusha, V. Ponnusamy, K.S. Rajan, Asian J. Chem. 27, 2523 (2015). 
15. Y. Aparna, K. Venkateswara Rao, P. Srinivasa Subbarao, J. Nano- Electron. Phys. 4, 03005 (2012).

16. N. Sundaramurthy, C. Parthiban, Int. Res. J. Eng. Technol. 2, 332 (2015)

17. K. Okaiyeto, M.O. Ojemaye, H. Hoppe, L.V. Mabinya, A.I. Okoh, Molecules 24, 4382 (2019).
18. F. Ljaz, S. Shahid, S.A. Khan, W. Ahmad, S. Zaman, Tropical J. Pharmaceutical Res. 16, 743 (2017).

19. R. Cuevas, N. Durán, M.C. Diez, G.R. Tortella, O. Rubilar, J. Nanomater. 2015, 789089 (2015).

\title{
Екологічний синтез наночастинок оксиду міді з рослинного екстракту catharanthus roseus та його дослідження
}

\author{
K. Sofiya Dayana ${ }^{1,2}$, R. Jothimani ${ }^{2,3}$, S.C. Vella Durai ${ }^{4}$ \\ ${ }^{1}$ Department of Physics, Sarah Tucker College (Autonomous), Tirunelveli 627007, Tamilnadu, India \\ ${ }^{2}$ Department of Physics, Sadakathullah Appa College (Autonomous), Tirunelveli 627011, Tamilnadu, India \\ ${ }^{3}$ Department of Physics, Fatima College for Women, Madurai 625001, Tamilnadu, India \\ ${ }^{4}$ Department of Physics, JP College of Arts and Science, Tenkasi 627852, Tamilnadu, India \\ (Affiliated to Manonmaniam Sundaranar University, Thirunelveli)
}

В останні роки нанотехнології е актуальною сферою для дослідників. Дослідження екологічного синтезу наночастинок (НЧ) оксидів металів проводились з різними рослинними екстрактами. Враховуючи величезні можливості рослин як джерел, ця робота передбачае екологічне виготовлення НЧ оксиду міді $(\mathrm{CuO})$ як варіант на заміну звичайних методів. Рослини обирають, щоб зменшити кількість металевих частинок за більш обмежений час, тоді як методи на основі мікроорганізмів вимагають більш тривалого часу. Проста доступність рослин у природі робить їх більш бажаними органічними активами, ніж мікроорганізми. НЧ $\mathrm{CuO}$ були введені за допомогою процедури екологічного синтезу з розчину мідного купоросу через водний екстракт catharanthus roseus. Було отримано незмінне співвідношення рослинного екстракту до іонів металу, а потім спостерігали зміну кольору, що довело утворення НЧ. Цей метод є швидким, простим, без небезпечних синтетичних речовин і доцільним для змішаних НЧ $\mathrm{CuO}$. Отримані НЧ аналізували за допомогою рентгенівської дифракції (XRD), спектроскопії UV-DRS, інфрачервоної спектроскопії з перетворенням Фур'е (FTIR), скануючої електронної мікроскопії (SEM) та зета-потенціалів. Підготовлені НЧ були отримані в діапазоні розмірів кристалітів 43,7 нм. Зображення SEM виявили, що форма НЧ е сферичною із середнім діаметром 43 нм. Аналіз FTIR підтвердив отримання піків $\mathrm{Cu}-\mathrm{O}$. CuO демонструе енергію прямої забороненої зони $2,04 \mathrm{eB}$ за допомогою спектроскопії UV-DRS. Проаналізовані зета-потенціали пояснили вузький діапазон стабільності НЧ. Завдяки унікальним фізико-хімічним властивостям та недорогій підготовці, $\mathrm{HЧ} \mathrm{CuO}$ викликають значний інтерес останнім часом. $\mathrm{HЧ} \mathrm{CuO}$ застосовуються як харчові добавки, мастила, складні сенсори, матеріали покриттів, незважаючи на незліченну кількість біотехнологічних і фрармацевтичних застосувань. У статті пояснюеться зручність застосування екстракту catharanthus roseus для ефективного приготування $\mathrm{HЧ} \mathrm{CuO}$ за допомогою екологічної технології синтезу.

Ключові слова: Catharanthus roseus, СuO, Екологічний синтез, Наночастинки, Зета-потенціал. 